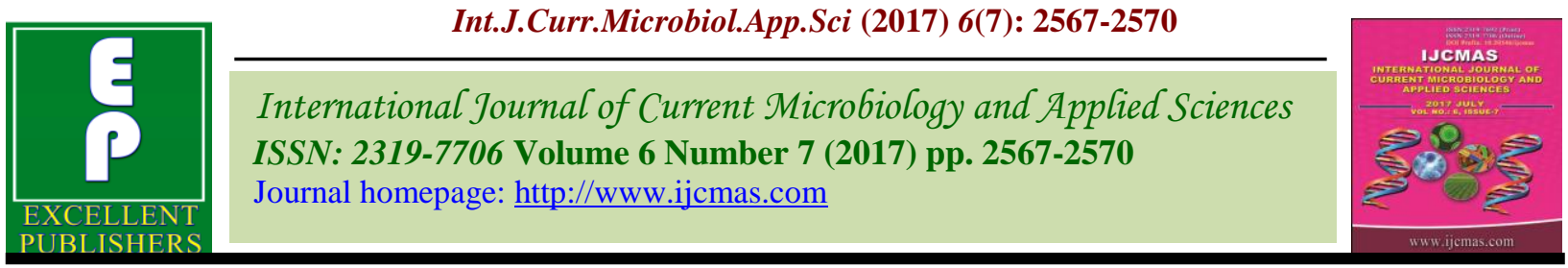

Original Research Article

https://doi.org/10.20546/ijcmas.2017.607.362

\title{
Optimization of Sulphur Dose for Chickpea (Cicer arietinum L.) Cultivars in Kymore Plateau of Madhya Pradesh, India
}

\author{
Vatsal Srivastav* and H.S. Kushwaha \\ Department of Natural Resource Management Mahatma Gandhi Chitrakoot Gramodaya \\ Vishwavidyalaya Chitrakoot, Satna (M.P.), India \\ *Corresponding author
}

\begin{abstract}
A B S T R A C T
An experiment was designed to assess the response of Sulphur to different Chickpea cultivars at Agriculture farm of Mahatma Gandhi Chitrakoot Gramodaya

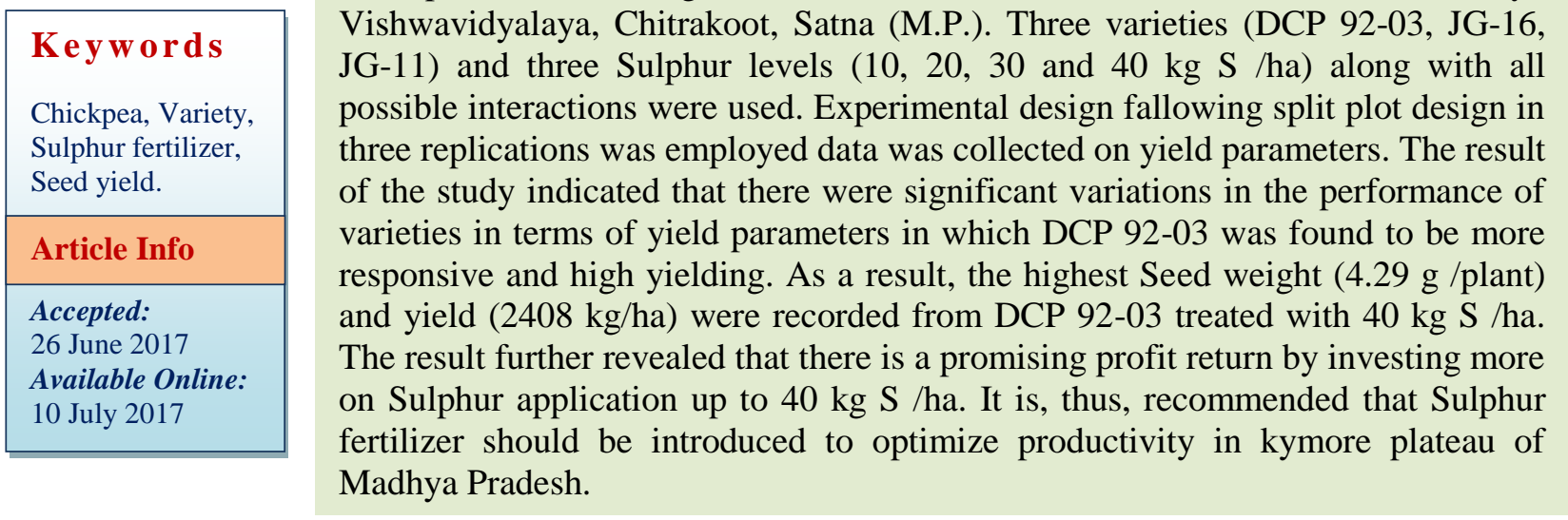

\section{Introduction}

Gram or Chickpea (Cicer arietinum L.), a member of family Fabaceae, is an ancient self-pollinated leguminous crop, diploid annual ( $2 \mathrm{~N}=16$ chromosomes) grown since 7000 BC, in different area of the world (Tekeoglu et al., 2000) Archaeological records bestow information that the cultivated chickpea was the first grain legume to be domesticated in the Old World. Chick pea contains $21 \%$ protein, $2.2 \%$ fat, $62 \%$ carbohydrates. It also contains calcium of about $190 \mathrm{mg} / 100 \mathrm{~g}$; Iron $90.5 \mathrm{mg} / 100 \mathrm{~g}$; Phosphorus $280 \mathrm{mg} / 100 \mathrm{~g}$. Among the pulses, chick pea has relatively lower protein content but of higher biological value and protein digestibility. An acid liquid from the granular hairs of leaves and pods contains two acids. They are (i) Malic Acid (90-96\%) (ii) Oxalic Acid (4-10\%) which are used in the preparation of drugs, and are prescribed for the intestinaldis-orders and blood purification. Moreover, the leaves are used to cure chronic bronchitis and the seeds are considered as antibilious, used as tonic, stimulant and aphrodisiac acid is also supposed to lower the blood cholesterol level. Due to its aphrodisiac properties, it is referred as vajibhakshya in Sanskrit. Chickpea has also the property to act 
as hypocholesteremic agent; germinating chickpea is believed to reduce the blood cholesterol level.

\section{Materials and Methods}

The Experiment was carried out during rabi season of 2015-16 on a well levelled field at Agriculture Farm of Mahatma Gandhi Chitrakoot Gramodaya Vishwavidyalaya, Chitrakoot, Satna (M.P.). The farm is situated in Bundelkhand region of Northern Madhya Pradesh. Geographically Chitrakoot is situated at $25^{\circ} 10^{\prime} \mathrm{N}$ latitude and $80^{\circ} 85^{\prime} \mathrm{E}$ longitude and about 190-210 meter above mean sea level. The climate of the area is semi-arid and sub-tropical with hot dry summer and cold winters. The total rainfall of Chitrakoot is $950 \mathrm{~mm}$ received in experimental area. Prior to planting of the potato crop, to find out the fertility status, a number of soil samples were taken randomly from the experimental field before the sowing of crop at the depth of $15 \mathrm{~cm}$. These samples were mixed together and a composite soil sample was drawn for chemical analysis. The field was prepared by one ploughing and one cross ploughing by cultivator. Planking was done after each ploughing to make soil friable for proper germination of seed. The recommended dose of nitrogen, phosphorus and potash for Chickpea was 20,40 and $20 \mathrm{~kg}$ per ha, which was provided through DAP, Urea and MOP Fertilizers were placed below the seeds at the time of sowing. Sulphur was applied as per the treatments. Under $\mathrm{S}_{3}$ it was applied as Basal at the rate of $30 \mathrm{~kg} / \mathrm{ha}$ and under $\mathrm{S}_{4}$ it was applied as basal at the rate of $40 \mathrm{~kg} / \mathrm{ha}$. Sowing was done as per treatment in rows $30 \mathrm{~cm}$ apart opened with the help of Kudal. Seeds were drilled in furrows and covered manually just after sowing. Two manual weeding were done in the experimental crop. First weeding was done with the help of Khurpi as to protect the crop from weed infestation while second intercultural operations were done when crop attains the age of about two months.

\section{Result and Discussion}

\section{Yield attributes and yield}

All yield and yield components studied in the present investigation were significantly influenced by the applied varieties and $S$ levels. However, number of Seed per plant was found to be significantly affected by the interaction treatments of varieties and $\mathrm{S}$ levels.

\section{Seed yield Kg/ha}

The variety DCP 92-03 $\left(\mathrm{V}_{1}\right)$ recorded significantly higher seed yield $(1789.99 \mathrm{~kg}$ /ha) which was $157.98 \%$ and $132.06 \%$ higher over JG-16 $\left(\mathrm{V}_{2}\right)$ and JG-11 $\left(\mathrm{V}_{3}\right)$ respectively. Highest seed yield $(1421 \mathrm{~kg} / \mathrm{ha})$ noted with $40 \mathrm{~kg} \mathrm{~S} / \mathrm{ha}\left(\mathrm{S}_{4}\right)$ level which was $80.32,40.97$ and $26.64 \%$ significantly superior seed yield over $10 \mathrm{~kg} \mathrm{~S} / \mathrm{ha}\left(\mathrm{S}_{1}\right), 20 \mathrm{~kg} \mathrm{~S} / \mathrm{ha}\left(\mathrm{S}_{2}\right)$ and 30 $\mathrm{kg} \mathrm{S} / \mathrm{ha}\left(\mathrm{S}_{3}\right)$ level. $30 \mathrm{~kg}$ significantly higher seed yield over $10 \mathrm{~kg} \mathrm{~S} / \mathrm{ha}\left(\mathrm{S}_{1}\right)$ and $20 \mathrm{~kg}$ $\mathrm{S} /$ ha $\left(\mathrm{S}_{2}\right)$. Treatment $40 \mathrm{~kg} \mathrm{~S} / \mathrm{ha}\left(\mathrm{S}_{4}\right)$ show higher seed yield over $30 \mathrm{~kg} \mathrm{~S} / \mathrm{ha}\left(\mathrm{S}_{3}\right)$ but did not touch the levels of significance in all the three varieties. Thus, the variety $\left(\mathrm{V}_{1}\right)(\mathrm{DCP}$ 92-03) with $40 \mathrm{~kg} \mathrm{~S} / \mathrm{ha}\left(\mathrm{V}_{1} \mathrm{~S}_{4}\right)$ resulted in significantly higher seed yield ( $2408 \mathrm{Kg} / \mathrm{ha})$

\section{Straw yield Kg/ha}

The variety DCP 92-03 $\left(\mathrm{V}_{1}\right)$ recorded significantly highest straw yield $(3290 \mathrm{~kg} /$ ha) which was significantly higher over JG-16 $\left(\mathrm{V}_{2}\right)(1924 \mathrm{~kg} / \mathrm{ha})$ and JG-11 $\left(\mathrm{V}_{3}\right)(1808$ $\mathrm{kg} / \mathrm{ha})$. Highest straw yield $(2534 \mathrm{~kg} / \mathrm{ha})$ noted with $40 \mathrm{~kg} \mathrm{~S} / \mathrm{ha}\left(\mathrm{S}_{4}\right)$ level which was significantly superior over $10 \mathrm{~kg} \mathrm{~S} / \mathrm{ha}\left(\mathrm{S}_{1}\right)$ but statistically at par with $20 \mathrm{~kg} \mathrm{~S} / \mathrm{ha}\left(\mathbf{S}_{2}\right)$ and 30 $\mathrm{kg} \mathrm{S} / \mathrm{ha}^{-1}\left(\mathrm{~S}_{3}\right)$, respectively. 


\section{Harvest index (\%)}

Harvest index observed to be $26 \%$ to $35 \%$ percent under different varieties of chickpea. It is clear from the results, that the varieties DCP 92-03 $\left(\mathrm{V}_{1}\right)$ recorded significantly higher harvest index over JG-11 ( $\left.\mathrm{V}_{3}\right)$ and JG-16 $\left(\mathrm{V}_{2}\right)$ However, Variety JG-11 $\left(\mathrm{V}_{3}\right)$ was also noted higher harvest index over JG-16 $\left(\mathrm{V}_{2}\right)$ increase the harvest index significantly up to
$30 \mathrm{~kg} \mathrm{~S} / \mathrm{ha}^{-1}\left(\mathrm{~S}_{3}\right)$ thereafter it was slightly increased but remains at par. Maximum harvest index (34\%) noted with $40 \mathrm{~kg} \mathrm{~S} / \mathrm{ha}^{-1}$ $\left(\mathrm{S}_{4}\right)$ level which was significantly superior over $10 \mathrm{~kg} \mathrm{~S} / \mathrm{ha}^{-1}\left(\mathrm{~S}_{1}\right)$ and $20 \mathrm{~kg} \mathrm{~S} / \mathrm{ha}^{-1}\left(\mathrm{~S}_{2}\right)$ levels but statistically at par with $30 \mathrm{~kg} \mathrm{~S} / \mathrm{ha}^{-1}$ $\left(S_{3}\right)$ Whereas, $30 \mathrm{~kg} \mathrm{~S} / \mathrm{ha}^{-1}\left(S_{3}\right)$ also recorded significantly higher harvest index over $10 \mathrm{~kg}$ $\mathrm{S} / \mathrm{ha}^{-1}\left(\mathrm{~S}_{1}\right)$ and $20 \mathrm{~kg} \mathrm{~S} / \mathrm{ha}^{-1}\left(\mathrm{~S}_{2}\right)$ treatment.

Table.1 Yield and yield components influenced by different treatment levels

\begin{tabular}{|c|c|c|c|c|c|c|c|}
\hline Treatment & $\begin{array}{l}\text { Seed } \\
\text { yield } \\
\text { (kg/ha) }\end{array}$ & $\begin{array}{l}\text { Straw } \\
\text { yield } \\
\text { (kg/ha) }\end{array}$ & $\begin{array}{l}\text { Harvest } \\
\text { index } \\
(\%)\end{array}$ & $\begin{array}{l}\text { Cost of } \\
\text { cultivation }\end{array}$ & $\begin{array}{l}\text { Gross } \\
\text { return }\end{array}$ & $\begin{array}{l}\text { Net } \\
\text { return }\end{array}$ & $\begin{array}{l}\text { B:C } \\
\text { ratio }\end{array}$ \\
\hline \multicolumn{8}{|l|}{ (A) Cultivars } \\
\hline $\mathrm{V}_{1}:$ DCP 92-03 & 1790 & 3290 & 35 & 27465 & 104989 & 77424 & 3.8 \\
\hline $\mathrm{V}_{2}: \mathrm{JG}-16$ & 693 & 1924 & 26 & 23265 & 42247 & 18982 & 1.8 \\
\hline $\mathrm{V}_{3}: \mathrm{JG}-11$ & 771 & 1808 & 30 & 23265 & 46147 & 22882 & 1.9 \\
\hline S.E m.. \pm & 73 & 97 & 2 & & 4019 & 4021 & 0.14 \\
\hline C.D. $(\mathrm{P}=0.05)$ & 217 & 290 & 5 & & 11942 & 11948 & 0.43 \\
\hline \multicolumn{8}{|c|}{ 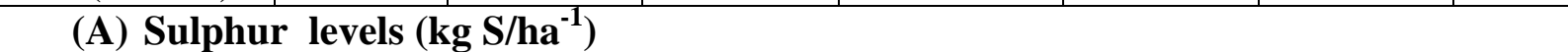 } \\
\hline $\mathrm{S}_{1}: 10$ & 788 & 2186 & 26 & 23616 & 47871 & 24255 & 1.9 \\
\hline $\mathrm{S}_{2}: 20$ & 1008 & 2373 & 29 & 24315 & 60268 & 35953 & 2.4 \\
\hline$S_{3}: 30$ & 1122 & 2269 & 32 & 25015 & 66416 & 41401 & 2.8 \\
\hline $\mathrm{S}_{4}: 40$ & 1421 & 2534 & 34 & 25715 & 83289 & 57574 & 3.1 \\
\hline S.E. m.t. & 45 & 105 & 1 & & 2541 & 2541 & 0.097 \\
\hline C.D. $(\mathrm{P}=0.05)$ & 135 & 312 & 3 & & 7549 & 7551 & 0.29 \\
\hline
\end{tabular}

\section{Economics}

The highest gross and net income of Rs.104989/- and Rs 77524/- was recorded under $\left(\mathrm{V}_{1}\right)$ (DCP 92-03). The variety JG-16 $\left(\mathrm{V}_{2}\right)$ gave the minimum gross and net income. Under different varieties of chickpea, highest $\mathrm{B}: \mathrm{C}$ ratio (3.805) was obtained from DCP 92$03\left(\mathrm{~V}_{1}\right)$, Whereas minimum B:C ratio (1.80) under JG-16 $\left(\mathrm{V}_{2}\right)$ Under different levels of Sulphur $40 \mathrm{~kg} \mathrm{~S} / \mathrm{ha}^{-1}\left(\mathrm{~S}_{4}\right)$ gave highest gross and net income of Rs. $83289 / \mathrm{ha}^{-1}$ and Rs. $57574 / \mathrm{ha}^{-1}$ which is followed by $30 \mathrm{~kg}$ $\mathrm{S} / \mathrm{ha}^{-1}\left(\mathrm{~S}_{3}\right)$ with Gross returns (Rs.66416/ha 1 and Net returns Rs.41401/ha ${ }^{-1}$ ) and minimum (Gross returns Rs.47871 and Net returns
Rs.24255/ha $\left.{ }^{-1}\right)$ under $10 \quad \mathrm{~kg} \quad \mathrm{~S} / \mathrm{ha}^{-1}\left(\mathrm{~S}_{1}\right)$. Highest net income of Rs.57574/ha ${ }^{-1}$ and B:C ratio (3.14) were recorded with $40 \mathrm{~kg} \mathrm{~S} / \mathrm{ha}^{-1}$ $\left(\mathrm{S}_{4}\right)$ respectively (Table 1$)$.

In conclusion, the variety DCP 92-03 gave higher seed yield, net returns an $\mathrm{B}: \mathrm{C}$ ratio as compared to other varieties in the Kymore Plateau of Madhya Pradesh. Application of 40 $\mathrm{kg} \mathrm{S} / \mathrm{ha}^{-1}$ gave higher nodulation parameters. yield attributes and seed yield of chickpea. Maximum net return and B: C ratio was obtained under DCP 92-03 and Sulphur $40 \mathrm{~kg}$ $\mathrm{S} / \mathrm{ha}^{-1}$. The variety DCP 92-03 with Sulphur @ $40 \mathrm{~kg} \quad \mathrm{~S} / \mathrm{ha}^{-1}$ recorded significant maximum seed and straw yield and net return 
of chickpea. Finally chickpea variety DCP 9203 grown with $40 \mathrm{~kg} \mathrm{~S} / \mathrm{ha}^{-1}+100 \%$ of RDF seed treatment by Rhizobium and PSB culture under Kymore Plateau of Madhya Pradesh was found best treatment for obtaining higher seed yield of chickpea with highest net returns and benefit cost ratio.

\section{References}

Chaudhary, V. K and Goswami, V.K. 2005. Effect of phosphorus and sulphur fertilization on chickpea. Cicer arietinum L.. cultivar. Annals of Agri. Res., 26(2): 322-323.

Dwivedi, G.K., Singh, V.P. 1982. Effect of phosphorus and sulphur application on the nutrition quality of different varieties of Bengal gram Increasing rates of $\mathrm{P}_{2} \mathrm{O}_{5}$ from 0 to $60 \mathrm{~kg} / \mathrm{ha}$ applied to Bengal gram. Indian J. Agron., 27(1): 7-12.

Mathur, Murari Lai, A.K., Purohit, H.S. Meena, R.H. Solanki, R.L. 2013. Effect of phosphorus and sulfur on yield, quality and nutrient uptake by chickpea. Cicer arietinum L). Environ. Ecol. 3101A, 325327.

Mondal, S.S., Manual, P., Saha, M., Bag, A., Nayak, S., Sounda, G. 2005. Effect of potassium and sulphur on the productivity, nutrient uptake and quality improvement of chickpea. J. Crop and Weed, 1(2): 84-86.

Mukesh Chand, et al. 2010. studied three dates of sowing viz., 15 october, 25october and 5 November in relation to four chickpea cultivars viz., K 850, Avrodhi, Radhey and KGD 1168 during rabi season of
2004-05 and 2005-06 to find out optimum time of sowing and suitable cultivar for sustainable production in the region.

Singh, Y.P., Smita Chaudhary. 2006. Response of varieties to sources of phosphorus and irrigation schedule on growth, quality, yield sulphur uptake and water use by chickpea. Cicer arietinum L. Res. Crops, 7(1): 84-87.

Subbiab, B.V. and Asija, G.L. 1956. A rapid procedure for the estimation of available nitrogen in soils. Curr. Sci., 25: 259-260.

Tandon, H.L.S. 2010. Soil sulphur deficiencies: towards integration of diverse data bases, Ind. J. Fertilizers, 6: 14-24.

Tandon, H.L.S. 1995. Sulphur in Indian Agriculture: update 1995. Sulphur in Agri., 19: 3-8.

Togay, N., Togay, Y., Cimrin, K.M., Turan. 2008. Academic Journals, Nairobi, Kenya, African Journal of Biotechnology, 2008, 7, 6, 776-782, 25 ref Effects of rhizobium inoculation, sulfur and phosphorus applications on yield, yield components and nutrient uptakes in chickpea

Tripathi, H.C., Pathak, R.K., Kumar Anil and Dimree, S. 2011. Effect of Sulphur and Zinc on yield attributes, yield and nutrient uptake in chickpea. Ann. Pi. Soil Res., 13(2): 134-136.

Tripathi, H.C., Singh, R.S. Mishra V.K. 1997. Effect of $\mathrm{S}$ and $\mathrm{Zn}$ nutrition on yield and quality of chickpea. J. Indian Soc. Soil Sci., 45.

Tripathi, et al. 1997. reported that the chickpea responded significantly to the application of S and Zn on Typic Ustochrept.

\section{How to cite this article:}

Vatsal Srivastav and Kushwaha, H.S. 2017. Optimization of Sulphur Dose for Chickpea (Cicer arietinum L.) Cultivars in Kymore Plateau of Madhya Pradesh. Int.J.Curr.Microbiol.App.Sci. 6(7): 2567-2570. doi: https://doi.org/10.20546/ijcmas.2017.607.362 